\title{
A SUSTAINABLE GROWTH OF CLEAN ENERGY IN INDIA: A TARGET 2022
}

\author{
Ashish Singhal ${ }^{1}$, Narendra Singh Beniwal ${ }^{2}$, Ramlakhan Patel ${ }^{3}$ \\ ${ }^{1}$ Research Scholar, Dr. A.P.J. Abdul Kalam Technical University, Lucknow, U.P, India \\ ashishee@gmail.com, \\ ${ }^{2}$ Associate Professor, Bundelkhand Institute of Engineering \&Technology, Jhansi, U.P, India \\ narendra.beniwal@gmail.com \\ ${ }^{3}$ M.tech Scholar, Sagar Institute of Science Technology and Engineering, Bhopal (M.P.) \\ rpatelbpl@gmail.com
}

\begin{abstract}
The extenuation of non-conventional global energy demands and changing environments is one of the most important ingredients in recent days. A case is about the study of sun energy acquired as clean energy by the government of India (GOI). GOI announced the various schemes for solar energy (SE) in the last decades because of the tremendous growth of solar energy aspects for the non-conventional sources with the support of central and state government. This article covered the progress of solar energy in India with major achievements. In this review article, the authors are trying to show the targets of the government of India (GOI) by 2022 and his vintage battle to set up a plant of solar or clean energy in India. This paper also emphasizes the different policies of GOI to schooling the people for creating the jobs in different projects like "Make in India". This paper projected the work of the dynamic Prime Minister of India Mr. Narendra Modi and his bravura performance to increase the targets 100 GW solar energy by 2022 .
\end{abstract}

Keywords: Clean (Solar) Energy (SE), Photovoltaic(PV), Energy demand, Government of India schemes (GOIs).

\section{Introduction}

One of the flexible industries is the renewable energy market. Demand for renewable energy(RE) has increased tremendously in the agricultural, manufacturing, commercial, and household sectors, placing immense pressure on its resources. Due to the shortage of resources and the growing contamination of the atmosphere due to the utilization of energy, optimal use of its resources has been needed, which in turn needs adequate energy planning to achieve energy protection. The last five-year installed capacity status in India was-

- India, having an installed capacity of $\mathbf{1 7 5 . 5 1 5}$ Giga Watt (GW) as of 31.03.2012 in which Thermal and Renewable contributed is 112.022 GW and 63.493 GW respectively.
- $\quad$ India, having an installed capacity of $246.162 \mathrm{GW}$ as of 31.03.2015 in which Thermal and Renewable contributed is 169.112 GW and 77.044 GW respectively.

- India, having a capacity of $270.682 \mathbf{G W}$ as of 31.03.2016 in which Thermal and Renewable contributed is 185.172 GW and 85.510 GW respectively.

According to the International Energy Agency (IEA), India will generate between $\mathbf{6 0 0}$ GW and 1200 GW of supplementary new power generation capacity before 2050 [1]

India's electricity during $2016-17$ and $2021-22$ is projected to be at least 1392TWh and 1915TWh, with peak electric demand of 218 GW and 298 GW respectively. Indian government endorses the various projects in the field of renewal energy sources, especially in solar energy.

\section{Solar energy in India \\ 3.1 Overview}

Solar power a clean and green renewal resource with a 'no' emission effect has got very high potential energy. As far as the graphical location of India is concerned, It has huge potential for sustainable development with help of solar energy which is transformed directly through PV technology [1-3], where light is transformed directly into electrical energy. In 2007, to promote the electronics and IT industries, India implemented a semiconductor policy. It includes the processing industry of silicon and PV. International Energy Agency (IEA) has categorized PV uses in four groups, i.e. domestic and non-domestic offgrid, distributed connected grid, and centralized connected grid. A standard PV module consists of approximately $6,36,72$ or 144 cells connected in series and parallel, mounted with an aluminium structure based on the application of the cell. Among renewable energy technologies, the rise of PV technology is mainly due to its discord, atoxic emissions, and relatively easy 
operation and maintenance. Global average irradiation is about $5 \mathrm{kWh}$ per square meter per day, with sunlight in most parts of India varying between 2300 and $3200 \mathrm{~h}$ per year[5,6]. The average incidence of solar radiation over India ranges from $4 \mathrm{kWh} /$ day to $7 \mathrm{kWh} /$ day. It is estimated that the solar radiation obtained over the Indian land area is around 5000 trillion $\mathrm{kWh} /$ year. India is currently the third-largest electricity generating country in the world, with a capacity of 1423 TWh in 2016 , of which $25 \%$ is from the hydro plant, $64 \%$ is from the thermal plant, $3 \%$ from the nuclear plant and around $8 \%$ is from renewable energy(RE) plant. India set the target for 2022 is $1894.72 \mathrm{TWh}$. In this paper, RE refers to small hydro plants, wind plants, biomass-based power generation plants, and solar-based plants [8]. The installation of solar power (SP) in India until Mar 31, 2016, is 6763 MW, as shown in Table 1. The capacity installed for grid-connected solar power was 4229.36 MW as of 31 Aug 2015.

\subsection{Growth of solar in India}

The Prime Minister of India has been launched the Jawaharlal Nehru National Solar Mission (JNNSM) on January 11, 2010. The mission has set the ambitious goal of achieving faster growth by employing

$$
\begin{aligned}
& \text { - } \quad \text { large scale deployment goals } \\
& \text { - } \quad \text { incisive R\&D } \\
& \text { - } \quad \text { long term policy }
\end{aligned}
$$

This mission will build a structure to achieve this aim. A 70 percent subsidy is provided by the MNRE for the construction

\begin{tabular}{|c|c|c|c|}
\hline State & MW as of 31-03-2015 & MW as of 31-03-2016 & MW as of 31-12-2016 \\
\hline Rajasthan(RJ) & 942.1 & $1,269.93$ & $1,317.64$ \\
\hline Punjab(PB) & 185.27 & 405.06 & 545.43 \\
\hline Uttar Pradesh(UP) & 71.26 & 143.5 & 239.26 \\
\hline Uttarakhand(UK) & 5 & 41.15 & 45.1 \\
\hline Haryana(HR) & 12.8 & 15.39 & 53.27 \\
\hline Delhi(DL) & 5.47 & 14.28 & 38.78 \\
\hline $\mathrm{J} \& \mathrm{k}$ & 0 & 1 & 1 \\
\hline Chandigarh(CD) & 4.5 & 6.81 & 16.2 \\
\hline Himachal Pradesh(HP) & 0.2 & 0.2 & 0.33 \\
\hline Northern Region & & & $2,097.72$ \\
\hline Gujarat(GJ) & $1,000.05$ & $1,119.17$ & $1,158.50$ \\
\hline Maharashtra(MH) & 360.75 & 385.76 & 430.46 \\
\hline Chhattisgarh (CS) & 7.6 & 93.58 & 135.19 \\
\hline Madhya Pradesh(MP) & 558.58 & 776.37 & 840.35 \\
\hline D\&N & 0 & 0 & 0.6 \\
\hline Goa & 0 & 0 & 0.05 \\
\hline Daman \& Diu & 0 & 4 & 4 \\
\hline Western Region & & & $2,464.91$ \\
\hline Tamil Nadu(TN) & 142.58 & $1,061.82$ & $1,590.97$ \\
\hline Andhra Pradesh(AP) & 137.85 & 572.97 & 979.65 \\
\hline Telangana(TL) & 167.05 & 527.84 & 973.41 \\
\hline Kerala & 0.03 & 13.05 & 15.86 \\
\hline Karnataka & 77.22 & 145.46 & 327.53 \\
\hline
\end{tabular}
cost of a solar PV power plant in the North-East States and a 30 percent subsidy for other regions [2].

Table 1 Region wise Generation of Solar Energy [5] 


\section{Puducherry \\ Southern Region}

Bihar

Odisha

Jharkhand

West Bengal

Sikkim

Eastern Region

Assam

Tripura

Arunachal Pradesh

Mizoram

Manipur

Meghalaya

Nagaland

\section{North Eastern Region}

Andaman \& Nicobar

Lakshadweep

Others

Islands and others
5.1

95.91

77.64

31.76

66.92

17.51

16.19

23.07

0.01

214.14

11.18

5.02

0.27

0.1

0.1

0.1

0.5

17.27

$\begin{array}{ccc}5.1 & 5.1 & 5.4 \\ 0.75 & 0.75 & 0.75\end{array}$

0
61.07

67.22

Total $\quad 3,743.97$

3. Present status and objectives of the Government of India (GOI)

Solar power has taken over biomass-based power generation technologies, according to recent statistics published by the MNRE (Ministry of New and Renewal Energy). Foreign Direct Investment (FDI ) in the RE sector is not limited by the Indian government [3].

India added 3,744 MW as shown in Table 1 of solar capacity by 31-March-2015 according to MNRE and the total installed capacity by 31 -Dec-2016 is 9,013 MW as shown in Table 1 . By March 2017, India has many solar power opportunities of close to $20 \mathrm{GW}$. According to the Union Minister for Gas, Power, and Renewal Resources, Piyush Goyal, solar energy in the country has increased fourfold over the next fiscal year ending March 2017. The country's solar capacity currently

$\mathbf{6 , 7 6 2 . 8 5} \quad \mathbf{9 , 0 1 2 . 6 6}$

stands at about $6.5 \mathrm{GW}$. It will be $12 \mathrm{GW}$ in the next fiscal year[4].

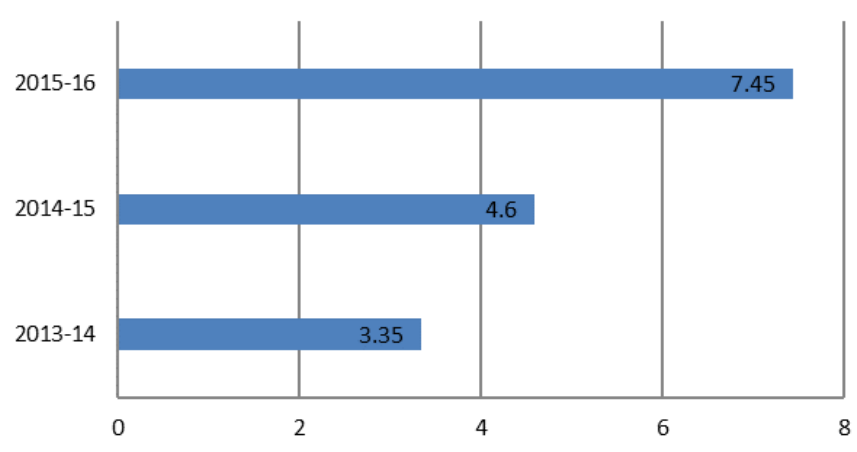

Figure 1 Yearly solar power generation (billion kWh) 


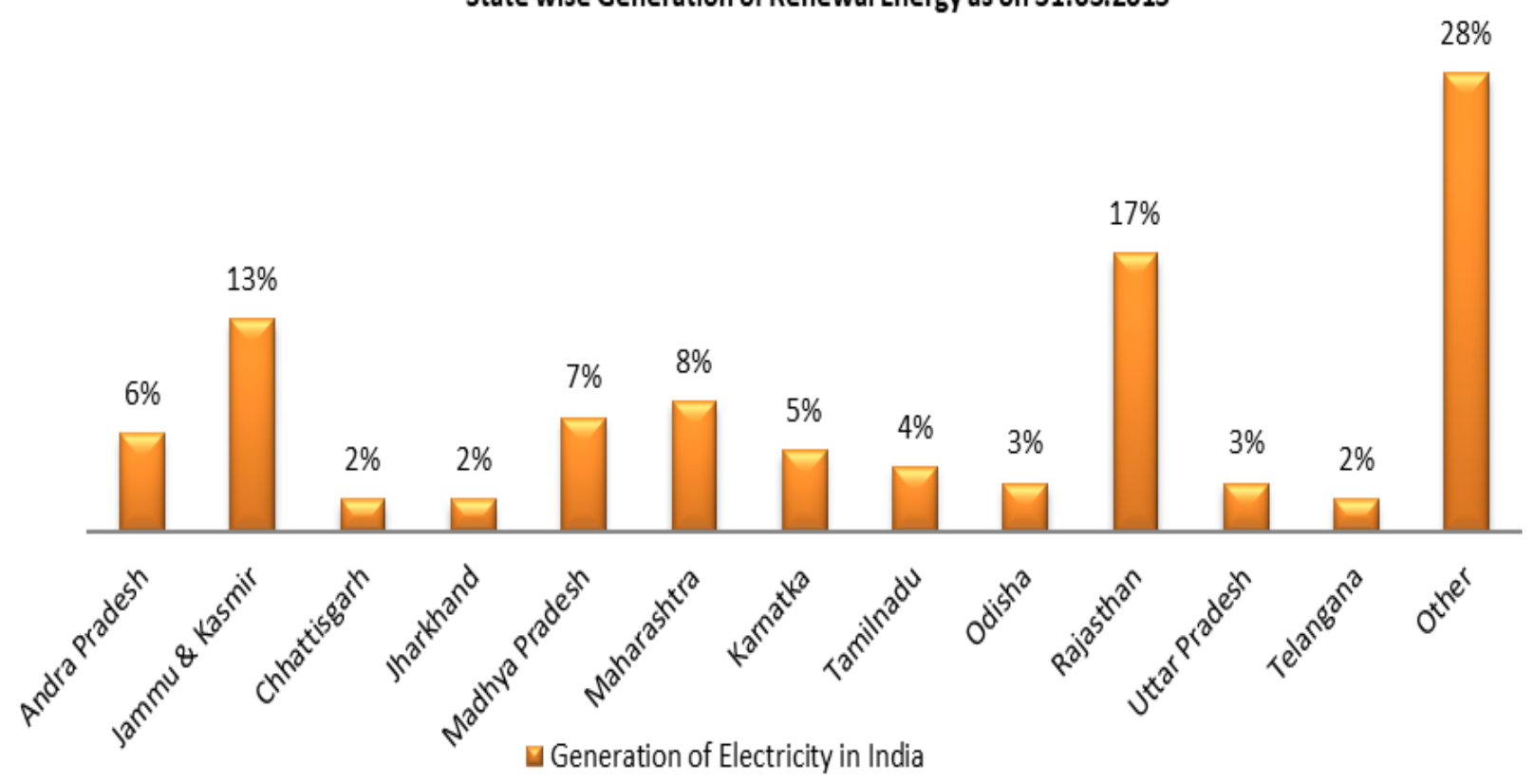

Figure 2 State-wise Generation of Renewal Energy

India's largest solar power plant will set up in India Madhya Pradesh district REWA with a capacity of $750 \mathrm{MW}$. It will be the largest plant in the world [9].

\subsection{Solar schemes in India}

India has taken several measures over the past decade to take advantage of the tremendous potential for RE sources. Indian Energy's objectives are to develop decentralized energy technologies based on renewable resources that are readily available on Earth. Since 1956, the government has been announcing many schemes [4]. From 2003 onwards, the government announced different policies and amendments to the electricity regulatory act for consumers including-

- The National Tariff Policy was drafted in the year 2006.

- Newly drafted policy on renewable energy.

- To create competition, Amendments were made to Electricity Act.

Since 1945, however, power generation has risen more than 100-fold. With an output of 1368 TWh in 2015, India is now the top three largest producers and sustain the third position from 2015-16 and the top fourth user of electricity in the world.

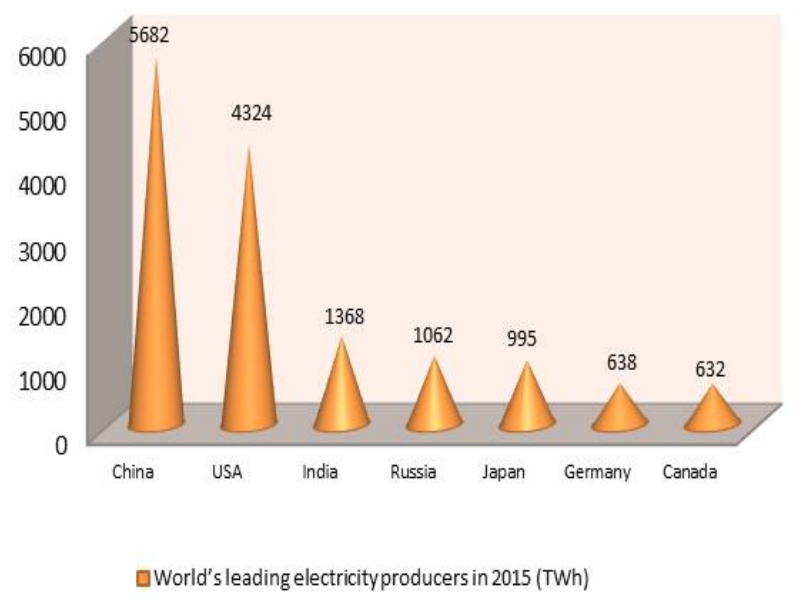

Figure 3 World's leading electricity producers in 2015 (TWh)

4.2 Limitations and advantages - solar energy, IndiaPerspective-[10]

- $\quad$ Our new Prime Minister (Shri Narendra Modi) has increased its previous approval to increase solar power capacity in India by five times under JNNSM, touching approximately $100 \mathrm{GW}$ by 2022 .

- $\quad$ About 6 Lac Cr. will be the overall expenditure in setting up $100 \mathrm{GW}$. During the first phase [11], the GOI is providing Rs. 15,050 $\mathrm{Cr}$ as a capital subsidy to encourage solar power.

- This capital subsidy will be given to the Rooftop Solar projects in several places of the cities and towns, to Viability Gap Funding (VGF)-based projects to be built through the Solar Energy Corporation of India (SECI) and to small solar projects for a decentralized generation [8]. 
4.3 Targets of the Government of India (GOI) regarding solar energy up to 2022

Table 2 GOI target up to 2022[7,9]

\begin{tabular}{lcccccccc}
\hline \multicolumn{1}{c}{ RE } & \multicolumn{7}{c}{ Year -wise Target(MW) } \\
\cline { 2 - 8 } Category & $\begin{array}{c}2015- \\
16\end{array}$ & $\begin{array}{c}2016- \\
17\end{array}$ & $2017-18$ & $2018-19$ & $2019-20$ & $\begin{array}{c}2020- \\
21\end{array}$ & $\begin{array}{c}2021- \\
22\end{array}$ & Total \\
\hline $\begin{array}{l}\text { Solar } \\
\text { Rooftop }\end{array}$ & 200 & 4,800 & 5,000 & 6,000 & 7,000 & 8,000 & 9,000 & 40,000 \\
$\begin{array}{l}\text { Solar } \\
\text { Projects }\end{array}$ & 1,800 & 7,200 & 10,000 & 10,000 & 10,000 & 9,500 & 8,500 & 57,000 \\
\hline Total & 2000 & 12000 & 15000 & 16000 & 17000 & 17500 & 17500 & 97000
\end{tabular}

${ }^{*} 6,763 \mathrm{MW}$ commissioned up to 2015-16

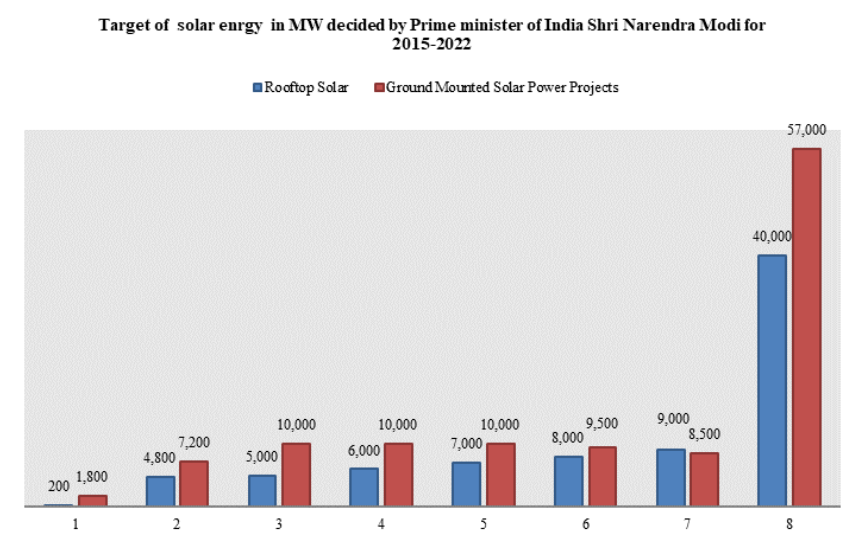

Figure 4 : Year-wise Target (MW) of Solar Energy

4.4 Advantages of solar energy in India

i. $\quad$ Growing demand

a. Reducing the $\mathrm{CO} 2$ emission

b. Environmentally friendly.

ii. Attractive opportunities

a. Ambitious projects have been introduced.

b. Diversification into renewable sources placed.

iii. Higher investments

a. Allowed for investment in the transmission system of the power grid.

b. From April 2000 to March 2016, total FDI inflows in India is accounting for 3.63 percent[6].

iv. Easily installation capability

a. In buildings, solar panels can be installed easily. It is, therefore, very inexpensive compared to other energy sources.

\subsection{Solar manufacturing Limitations}

India's manufacturing industry has developed over the past decade at CAGR constant prices of 7.3 percent. However, in 2012 and 2013, the growth rate of industrial output decreased. The share of GDP in production in 2013-14 was 14.9 percent, a decrease of 90 basis points compared to the previous FY 19. Instead of this, a positive attitude is shown by business leaders and the industry in general. In addition to the 0.1 percent raise over the same span last year, the Industrial Production Index (IPI) with the hikes of 2.1 percent in 2014-15 (Apr-Dec).
Output also increased in the first and second quarters of 201415 , respectively, by 3.9 percent and 0.4 percent. Reasons are given for,

- The very high cost of finances or initial capital.

- $\quad$ Competition from Taiwan \& China.

- Not so popular or Low demand in India.

Instead of this, company leaders and the industry, in general, are displaying a good outlook.

4.6 Make in India: A noble approach for employability empowerment

- GOI mandates the use of "Make in India" promoted the solar panels making with very fast growth from 2011-12 onwards.

- $\quad$ The government has announced several initiatives to help the domestic renewable industries. The GOI launched the National Manufacturing Policy (NMP) in 2011, which aims to raise manufacturing's share of GDP to 25 percent by 2021 , generating 100 million jobs in the process [7].

- The National Manufacturing Policy (NMP) was combined with the 'Make in India' initiative last year and a host of incentives were announced specifically for manufacturers of PV modules and module balances. The customs and excise duty exemption cover the majority of the incentives[8].

- The market prospects for the production of solar energy are important. India is a strong example of the realistic possibilities for solar energy production in Gujarat, Rajasthan, Tamilnadu, and Madhya Pradesh.[9].

\section{Initiatives by the Government of India (GOI)}

\subsection{Sun Power: A warm Initiatives}

- Under the National Solar Mission (NSM), the capacity setting target has risen from $20 \mathrm{GW}$ to $100 \mathrm{GW}$ by 2021-22. 10,500 MW target, set for 2016-17, which will take up the $17 \mathrm{GW}$ cumulative power until 31 March 2017[10].

- $\quad$ Several schemes, which are as follows

i. The scheme related to Defense

ii. The Central Public Sector Undertakings scheme(CPSUs)

iii. The Bundling scheme

iv. The Solar Park Scheme(SPS)

v. The Solar rooftops have been initiated and launched by the Ministry under National Solar Mission (NSM).

- $\quad$ A total of 90,710 solar pumps has been installed [11] on 31.10.2016.

- $\quad$ A total of Rs 67.01 Cr. The planning of the master plan, solar city cells, promotion activities, and construction of renewable energy projects and a sum of Rs $34.16 \mathrm{Cr}$ have been sanctioned. So far, the Under Solar City Program has been announced. 
- $\quad 34$ Solar Parks with a capacity of 20,000 MW have been approved in 21 states under different phases of implementation [12].

\subsection{Solar Rooftop}

- $\quad$ To target $40 \mathrm{GW}$, a major Grid Connected Solar Rooftop Program has been launched. Regulation Informed by the 30 States/UTs State Electricity Regulatory Commissions on the net-metering and feed-in-tariff system. The five thousand crore rupees approval for rooftop solar. By 30.09.2016, a solar rooftop capacity of approximately 500 MW was installed.

- The Ministry has connected all rooftop plants with ISRO for Geotagging using the VEDAS Portal of ISRO.

- A target for solar rooftops linked to the $40 \mathrm{GW}$ grid to be achieved by 2022 has been set. Approximately $500 \mathrm{MW}$ have been installed so far and approximately $3000 \mathrm{MW}$ that is under installation have been sanctioned. All major businesses, i.e. In addition to the private sector, railways, hospitals, educational institutions, and the central/state/PSU regulating buildings are targeted [13].

\subsection{Minimum Solar Tariffs}

- $\quad$ Solar tariffs for one of the six $70 \mathrm{MW}$ projects to be set up under the NSM in Rajasthan were reduced to an unprecedented low of Rs. 4.34/kWh via an auction. On 18.01.2016, the National Thermal Power Corporation (NTPC) made a reverse offer for $420 \mathrm{MW}$ solar energy ventures. However, as cited by Solar Energy Corporation of India (SECI)[14] in the Amplus Energy Solution auction for rooftop solar power, the tariff of the unit was further reduced to Rs 3 per unit.

\subsection{Skill development}

- At the National Rooftop Solar Power Workshop, on 07.06.2016, Shri Piyush Goyal, Minister of State for Water, Coal, and Renewal, unveiled the "Surya Mitra" mobile app. The National Institute of Solar Energy (NISE), the autonomous agency of the MNRE, provided the GPS-based mobile app.

- $\quad$ Suryamitra schemes have been introduced to build 50,000 qualified photovoltaic solar technicians by March 2020. As of 30.09.2016, a total of 5492 Suryamitras have been trained and more than 3000 are undergoing training. For the implementation of the Suryamitra scheme, The network of over 150 institutions, spread throughout the country, was established.

- $\quad$ During the last two years, about 7800, individuals have been successfully trained by these short-term training programs.

- $\quad$ Suryamitras are once again sensitized by Customer Relationship Management, Punctuality by NISE, or soft skills and are now able to provide the services.
- $\quad$ Besides, Many Short term programs (STTP) have been organized for hydro, entrepreneurship creation, solar energy system operation \& maintenance, and boiler operations in co-generation plants[15].

\subsection{Other important Initiatives}

- $\quad$ The International Solar Alliance (ISA) was launched at COP21 in Paris on 30 November 2015, with its headquarters in India.

- 100 percent of FDI is allowed under the automatic route for renewable energy generation and distribution projects under the Electricity Act, 2003[16].

- $\quad 30$ member countries, including India, France, Brazil, and others, signed the ISA Framework Agreement on the sidelines of COP-22 on 15 November 2016 in Marrakech, Morocco[17].

The MNRE has set various objectives for solar energy in the field of rooftop and Solar projects as seen in the table-2. These objectives are feasible and not only provide solar energy, but also create a new field to provide employment opportunities for millions of people. As of 31 December 2016, India's total installed grid-interactive solar power capacity is 9,012.66 MW, representing 18.1 percent of India's total renewable power capacity (50017.97 MW).

Since we know that the total installed capacity target in India is $175 \mathrm{GW}$ in the renewal or clean energy sector by 2022 in which Solar contributed $100 \mathrm{GW}$, it is easy to achieve by generating approximately $110,341 \mathrm{GW}$ per year by generating $3 \mathrm{GW}$ per year, which is more than $10 \%$ of India's total installed capacity target by 2022 in figure 6

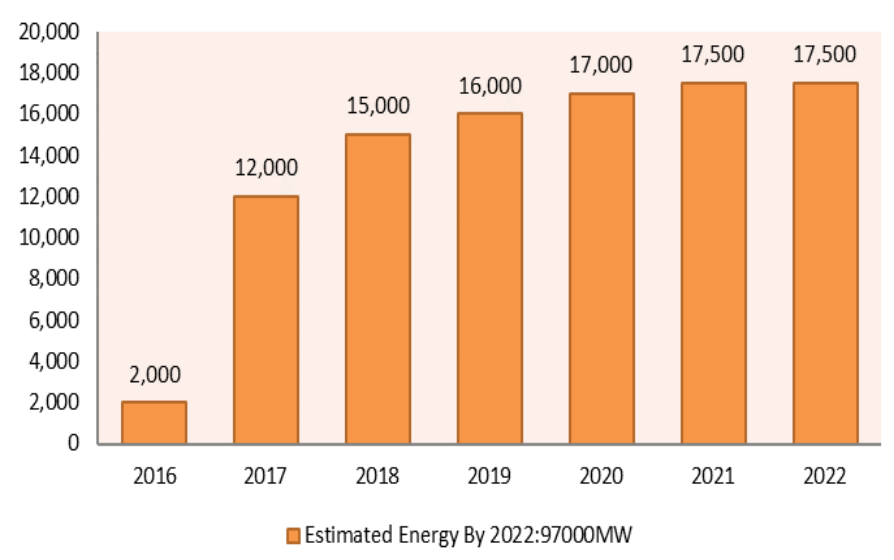

Figure 5: Estimated Energy by Financial Year (FY) 2022 


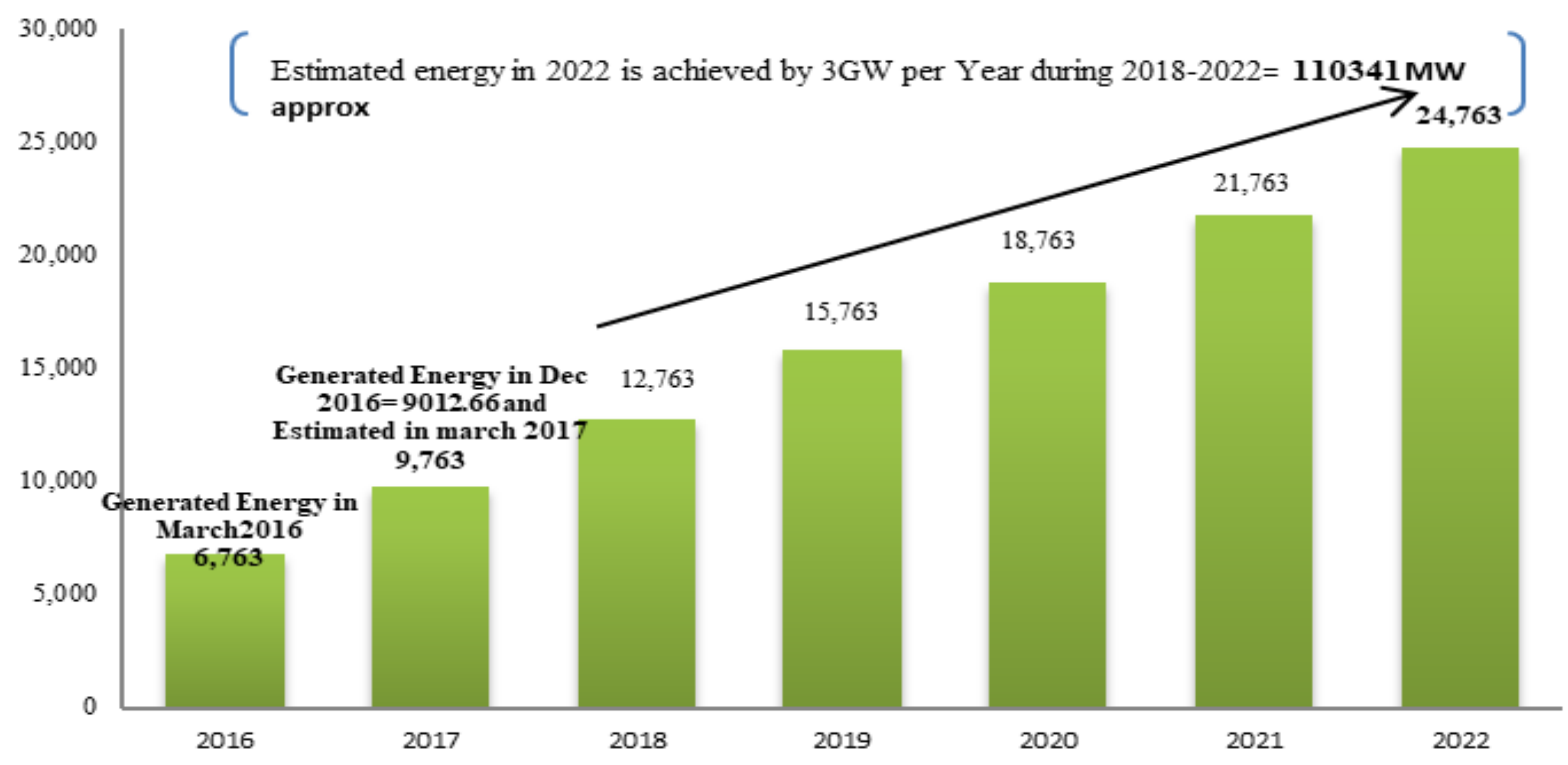

Estimated E nergy Achieved in MW as per generation during march 2016 and Dec 2016 up to 2022

\section{Conclusion}

This paper is a comprehensive study of India's strategy and policies under the visionary leadership of Narendra Modi, going to take in the upcoming years and also discussed the regional and state-wise generation of solar energy estimation for the target by 2022. In India, JUN-2015 to DEC-2017 are satisfactory during the year, but some attention is needed to improve its growth. This paper gives the idea of calculating and estimating as shown in figure 6, the generation of solar energy (Rooftop Solar \& Ground Mounted Solar Power Projects) during 2015-2022 and helps draw up the strategy to support "Make in India" and other significant policies. The authors attempt to emphasize the different policies and the objective of India's Prime Minister (Mr. Narendra Damodardas Modi Ji) to increase solar power under JNNSM in India, reaching $100 \mathrm{GW}$ by 2022 .

\section{Acknowledgments}

I as an author would like to acknowledge the financial support of TEQIP-3 RGPV Bhopal. This study was carried out at the Department of Electrical Engineering, Sagar Institute of Science Technology and Engineering, Bhopal (M.P.), India. For their valuable comments to enhance the content of the article, the writers would like to sincerely thank the reviewers.

\section{References}

[1] Madani A, Absalan M, Lohmann G, Anvari M, Rahimi MR. Strong short-term non-linearity of solar irradiance fluctuations. Solar Energy 2017;144:1-9.

[2] Singh, O., \& Gupta, S. K. (2018, March). A review on recent Mppt techniques for photovoltaic system.
In 2018 IEEMA Engineer Infinite Conference (eTechNxT) (pp. 1-6). IEEE.

[3] Sahoo SK. Renewable and sustainable energy reviews solar photovoltaic energy progress in India: A review. Renewable and Sustainable Energy Reviews 2016.

[4] Anand S, Gupta A, Tyagi SK. Solar cooling systems for climate change mitigation: A review. Renewable and Sustainable Energy Reviews 2015;41:143-61. doi:10.1016/j.rser.2014.08.042.

[5] Sharma A, Srivastava J, Kumar S, Kumar A. Wind energy status in India: A short review. Renewable and Sustainable Energy Reviews 2012;16:1157-64. doi:10.1016/j.rser.2011.11.018.

[6] Rekioua, D. (2020). MPPT methods in hybrid renewable energy systems. In Hybrid Renewable Energy Systems (pp. 79-138). Springer, Cham.

[7] Kabalci, E. (2017). Maximum power point tracking (MPPT) algorithms for photovoltaic systems. In Energy Harvesting and Energy Efficiency (pp. 205234). Springer, Cham.

[8] Kandpal TC, Broman L. Renewable energy education: A global status review. Renewable and Sustainable Energy Reviews 2014;34:300-24. doi:10.1016/j.rser.2014.02.039.

[9] Khare V, Nema S, Baredar P. APPLICATION OF GAME THEORY IN PV-WIND HYBRID SYSTEM 2012;2:25-32.

[10] Pillai IR, Banerjee R. Renewable energy in India : Status and potential. Energy 2009;34:970-80. doi:10.1016/j.energy.2008.10.016. 
[11] Ramachandra T V, Jain R, Krishnadas G. Hotspots of solar potential in India. Renewable and Sustainable Energy Reviews 2011;15:3178-86. doi:10.1016/j.rser.2011.04.007.

[12] Solangi KH, Islam MR, Saidur R, Rahim NA, Fayaz H. A review on global solar energy policy. Renewable and Sustainable Energy Reviews 2011;15:2149-63. doi:10.1016/j.rser.2011.01.007.

[13] Singh R, Sood YR. Current status and analysis of renewable promotional policies in Indian restructured power sector - A review. Renewable and Sustainable Energy Reviews 2011;15:657-64.

[14] Shrimali G, Nelson D, Goel S, Konda C, Kumar R. Renewable deployment in India: Financing costs and implications for policy. Energy Policy 2013;62:28-43. doi:10.1016/j.enpol.2013.07.071.

[15] Madani A, Absalan M, Lohmann G, Anvari M, Reza M, Tabar R. Strong short-term non-linearity of solar irradiance fluctuations 2017. doi:10.1016/j.solener.2017.01.008.

[16] Singhal AK, Yadav N, Beniwal NS. Global Solar Energy : A Review 2015;6:1828-33.

[17] Tyagi V V, Kaushik SC, Tyagi SK. Advancement in solar photovoltaic/thermal ( PV / T ) hybrid collector technology. Renewable and Sustainable Energy Reviews 2012;16:1383-98. doi:10.1016/j.rser.2011.12.013.

[18] Kashyap, K., Nayim, S. T. I., Thakur, R., Kumar, A., \& Thapa, S. (2020). A Study of Solar Energy in India; Utility, Status, and Procurement. In Intelligent Communication, Control and Devices (pp. 435-443). Springer, Singapore.https://doi.org/10.1007/978-981-138618-3_46. 